\title{
第83回日本内科学会講演会（1986年）
}

\section{シンポジゥム 血栓症の病態生理と治療}

2.（3）脳血栓に括ける凝固六進状態

鹿児島大学医学部第三内科

\section{序言}

近年脳血管性障害は減少しつつあり死因の第一 位の座を悪性腫瘍に譲つたが，高血圧の管理と救 急医療の確立に上り，脳出血は確実に減少したと はいえ, 脳梗塞は相対的に增加しており，その予 防は発症年令の高令化によつて評価され，脳血栓 の重要性はむしろ増加しつつある.

さて従来脳血栓の成因として主として動脈硬化 による血管の狭窄ないし閉塞が論じられてきた が，もし血液が水であつたら例えいかに血管が狭 くなつても灌流障害は抗こらない筈で，その意味 では血栓症発症の最終段階は血液凝固にあるとい らべきである。この立場からわれわれは脳血栓症 に打いて静脈血中の多くの凝固パラメータを測定 し，その病態を探りつつある。ささらに脳卒中はそ の名の示寸如く急性に発症するもので塞栓は別と して血管の狭窄だけではその急性発症の説明はで きず，急激な凝固能の亢進があつてはじめて血栓 症が発症し，一旦血栓が形成されても，血液凝固 因子の消費，線溶能の亢進ない乙凝固インヒビ ターの生成などによりそのプロセスはやがて下火 となり，症状は軽快してゆくことが多い，血液が 徐々に六進状態に傾くと，何らかのトリッガーが 加り，そのピークに達した時に血栓症が急性に発 症するもので，発症前の凝固元進状態を把握し対 策を講ずれば十分に予防が可能と考えられる（図 1 ).

静脈血中の凝固パラメーター

われわれは通常血栓症が発症してからのパラ

\section{井形昭弘 新名主宏一}

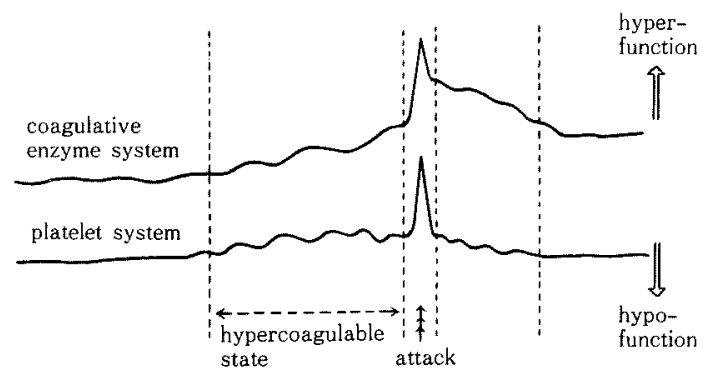

図 1，脳血栓症の発生機構

メータを見ているので，その情報は偏らざるをえ ないが，それでも殆どのパラメーターで凝固克進 状態があることを明らかにすることが出来た。 ず凝固酵素系については血中フィブリノーゲンの 量的な代償性増加ないし質的の異常が凝固能元進 に大きな因子をなし，特に後者に属する高分子 フィブリノーゲンないし可溶性フィブリンモ， マーコンプレックスは凝固亢進状態の一つの重要 な指標であり（図 2)，この存在は血液の粘度をも 方進させることを明らかにした。また凝固第XII 因子も血栓症では反応性に増加していることが多 く(図 3), さらに凝固第XIII因子の関与する〉1 ブリンの $\boldsymbol{\gamma}=\boldsymbol{\gamma}$ 架橋む凝固亢進の証拠となりらる ことを明らかにした(図 4)。ざらにフィブリン形 成時に出現するフィブリノペプタイドAないしB も凝集能え進のパラメータである，血中のアンチ トロンビンIIIは血栓形成に際し减少し血栓症か否 かを示す一つのパラメータであり（図 5)，また出 産後の血栓症, ピル服用後の血栓症, 前立腺癌の エステロジェン治療時の血栓症ではェストロジェ

Symposium on pathophysiology and treatment of thrombosis. (3) Hypercoagulative state in cerebral thrombosis.

Akihiro IGata and Kouichi Shinmyouzu, The Third Department of Internal Medicine Kagoshima University Hospital 
フィブリノーゲンの分子㖏

(clumping test on Biogel $\mathrm{A}-15 \mathrm{~m}$ )

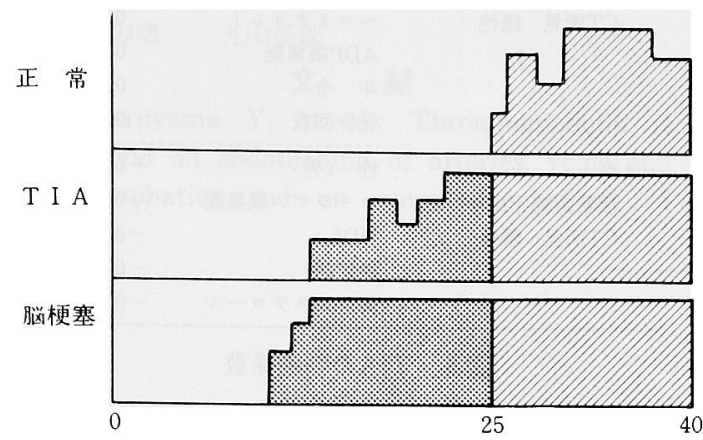

図 2. 高分子フィブリノーゲン（soluble fibrin monomarcomplex)

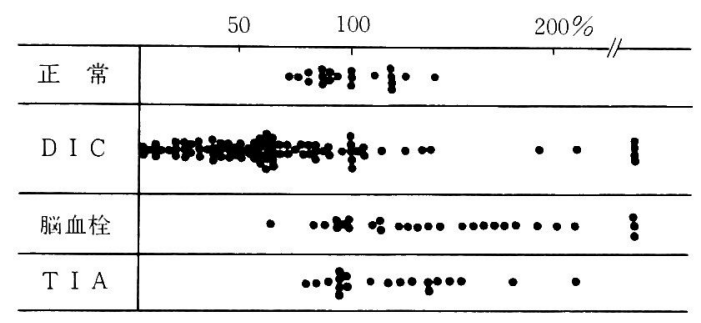

図 3. 血中XII因子の变動

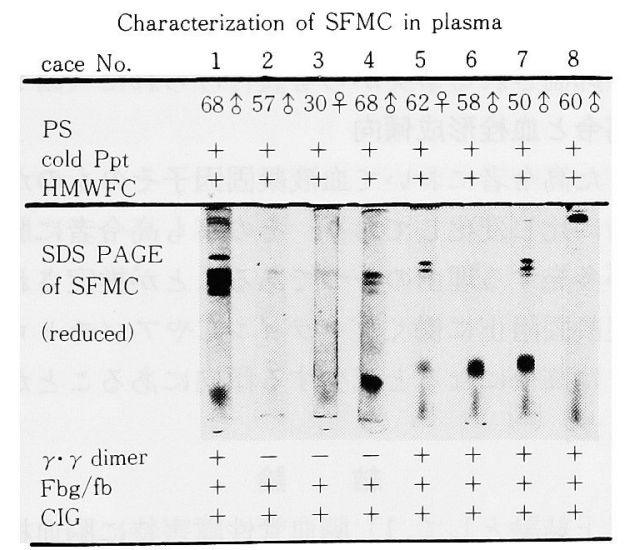

図 4 . 静脈血中 $\boldsymbol{\gamma}=\boldsymbol{\gamma}$ 架橋

ソのアンチトロンビン抑制作用が重要な役割を果 していることが明らかにされた。一方血小板系に も凝固亢進を示すパラメータが多く，凝集能元進 の他, 血中循環血小板凝集, ベータトロンボグロ ブリン，トロンボキサンB2, 6-keto PGf1 $\alpha$ どが 有用であつた。以上この両系の凝固諸因子を総合

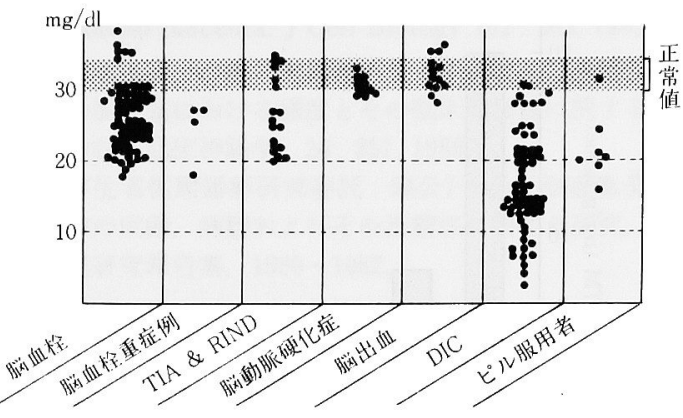

図 5.種々の病態に拈ける血中AT III

的に判断すると，脳卒中発作に際しそれが血栓症 であるか否かの判断にも治療効果の評価にも極め て有用であることが判明した，血液成分のほか当 然血管壁も血液凝固に関与するが動脈硬化の存在 を別としても，それとも関連するプロスタサイク リンないし6-ケトPGf $1 \alpha$, フォンウレブランド因 子が血中に凝固六進のパラメーターとして出現す るので㠜固え進状態の判断に有用な指標となりら る.

\section{脳血管の特殊性}

一方脳に打ける血管が他臟器のそれに比し血栓 症をきたし易い構造上ないし機能上の特殊性を有 している。ささら同じ脳血管でも静脈と動脈では 大きな相違があり，また動脈系でも穿通枝と皮質 枝とでは血液凝固能の上で機能上の差がある。こ のことは両血管系領域の血栓症群で種々のパラ メーターに差として証明された。この他最近脳血 管の特殊性として当教室の丸山は1), 凝固に関与 するトロンボモジュリンが血管壁に存在するこ と, およびこれが他臓器に比し脳血管壁には殆ど 存在しないことを明らかにした（図6）。この知見 は凝固六進状態に際し，先ず脳に血栓が起こり易 い可能性を示すものであり，脳血栓を考える上で 重要な指摘と言らべきであろう。

\section{先天性血栓形成傾向（図 7 )}

一方最近先天性の血栓形成傾向を示す病態が注 目されてきた。われわれはアンチトロンビンIII欠 乏症とプラズミノーゲン異常症を経験している が，この様な先天的の素因は事前に発見されてい ればその対策も可能となる。ただ後者のプラズミ 


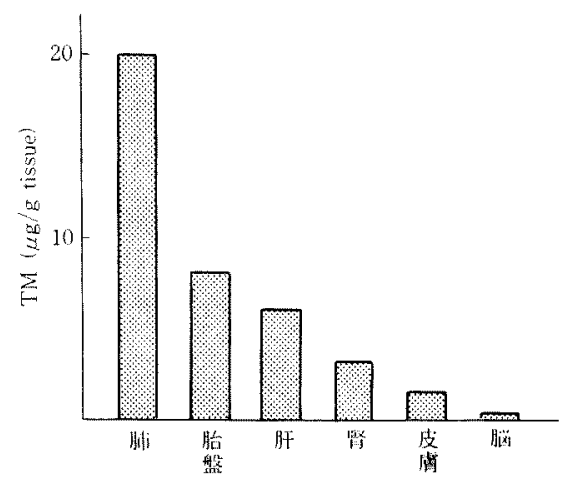

図6、各臓器のトロンボモジュリンの分布（丸山）

a. Antithrombin III deficiency or abnormality
b. Plasminogen abnormality or deficiency?
c. Protein C deficiency or abnormality
d. Plasminogen activator deficiency or abnor-
mality?
e. Fibrinogen abnormality

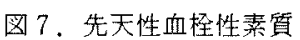

ノーゲン異常症ではへテロの異常症例は対照群に もほ添同率にみられ，直接的なリスクファクター とは考えられないことが推定されている2゙.また この様な凝固因子異常のさい, 他臟器に比し脳に 血栓がおこり易いことは注目に值する。この際動 脈血栓か静脈血栓かは大きな問題であるに関わら ず，従来あまり論じられていなかつたが凝固に血 管内被が関与しらる以上将来の大きな問題である う。一つの例として春骾の血栓症は脳血栓症に比 し極めて李れであるが，ここでは脳と異なり血厈 が低くその血流動態は静脈のそれに似て扣り，わ れわれは動脈と静脈の特徵をもつ春䯙の血栓の頻 度が低いことに大きな関心を持つている。

\section{一過性脳虚血発作}

一過性脳虚血性発作は言うまでもなく頭蓋外血 管病変よりの微少血栓によるとされていたが，わ

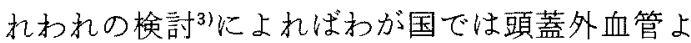
りむしろ頭蓋内の血管狭窄が原因と考壳られる例 が圧倒的に多く，特にこのTIAで麻痺が10分以上 続く症例を多数例で多変量解析で娭討した結果, TIAの多くは小さい脳血栓であることが推定され (図 8), 発作に際し血液凝固能六准が関与してい

\begin{tabular}{|c|c|c|}
\hline B群 & 高血压 & 1.75 \\
\hline 庭状持綂 10 分以上 & 中性脂肪 & 1.36 \\
\hline \multirow{4}{*}{$\begin{array}{c}\text { CT所見 陽性 } \\
\uparrow\end{array}$} & ヘマトクリット & 0.93 \\
\hline & ADP綎集能 & 0.91 \\
\hline & 年 令 & 0.14 \\
\hline & 発作回数 & 0.14 \\
\hline A群 & 性 (男) & -0.025 \\
\hline 症状持続 10 分以内 & コーラゲン懝集能 & -0.042 \\
\hline \multirow[t]{3}{*}{ CT所見 陰性 } & $\mathrm{HDL}$ & -0.17 \\
\hline & 精原病 & -0.31 \\
\hline & 棇コレステロール & -0.68 \\
\hline
\end{tabular}

図 8.TIAの判別係数

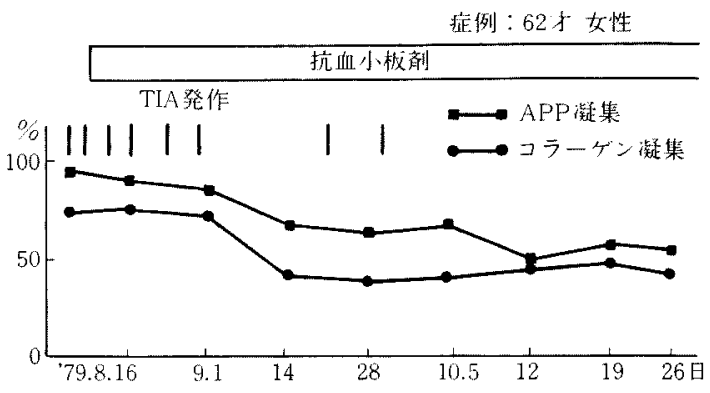

図 9.血小板凝集能とTIA発作回数

ることが明らかにされた。このこは抗血小板剂 などの抗凝固療法で，このTIA発作が注注完全に 近く抑制される事実から女亳付けられた（図 9).

\section{高令と血栓形成傾向}

また高令者に拈いて血液凝固因子そのものが若 年者に比し変化しており，その事も高令者に脳血 栓が多発する理由の一つであることが推定され， 事実凝固阻止に働くプロテインCやアンチトロン ビンは高令になると減少する傾向にあることが判 明した。

\section{結論}

以上結論として,1) 脳血管性障害特に脳血栓症 はわが国では依然として大きな問題であり，2）脳 血栓の発症には動脈硬化より血液凝固能元進の方 が大きな因子で，このことは静脈血中の凝固パラ メータから証明される.3）先天性の血栓形成傾向 が発見されつつある.4）TIAも凝固能六進が原因 のことが多く，その予防で抑制し得る。

以上血液凝固能え進の証明が脳血栓症の診断に 有用であり，かつそれに対する対策が脳血栓の治 
療のみならず，その予防にも極めて有用であるこ と指摘した。

研究協力者：丸山征郎

\section{文献}

1) Maruyama $Y$, et al: Thrombomodulin is found on endothelium of arteries, veins and lymphatics and on syncytiotrophoblast of human placenta. J Cell Biology 101: 363, 1985.

2）新名主宏一，他：先天性プラズミノーゲン異常症 の脳梗塞に扣ける頻度とその臨床的意義に関する 検討. 臨床神経学 $26: 257,1986$.

3）厚生省循環器病研究委託：54公7一過性脑虚血発 作の成因, 病態拉よびその治療法に関する研究。 同研究報告集, 1980 - 1982 . 